\title{
'Join and Escalate':
}

\section{Chris Crutcher's Coaches}

n Chris Crutcher's young adult novels, the main characters are advised (or abused), supported (or undermined), guided (or misguided) by official and unofficial athletic coaches. Through his carefully crafted portraits of good and bad coaches, Crutcher gives his readers a detailed outline of what he thinks it means to be a responsible role model for young people. The coaches who are the heroes in his books teach their young charges about the elements of the game in question (of course), but they also help teens find strength and determination. What they don't doat least the good ones-is try to make sports about patriotism, respect for authority, piety, or loyalty to one's school (or coach). They also refuse to tell kids what to do-or what to think-about the lives they've been given. The best coaches in Crutcher's novels give adolescents the tools to figure out the world for themselves.

Crutcher is concerned about the role that coaches play in the lives of young people because, as he says in his autobiography, King of the Mild Frontier (2003):

I look back and wish my athletic mentors had been able to present a larger picture and had celebrated the sport relative to the ability of the individual athlete. I wish they had made it clean, wish they hadn't made it patriotic, religious, moral. A sport has its own built-in integrity, doesn't need an artificial one. Athletics carries its own set of truths, and those truths are diminished when manipulated by people with agendas. So, in my stories, I let my characters try to find the purity, the juxtaposition of mind, body, and spirit that I discovered in athletics at a much later age. (256)

Crutcher's best coaches do just that: help the young adults in their care find "the purity, the juxta- position of mind, body, and spirit" in sports, and in their lives. His worst ones reveal how destructive, angry, hypocritical, domineering, and/or racist adults can be. Still, they, too, are not without value: Crutcher believes that learning how to resist such bullies positively and creatively is a necessary life skill.

Even well-intentioned adults can do damage, however, especially if they try to shield children from the difficult truths about life. Crutcher reaffirms in his autobiography what he has said in numerous interviews and emphasizes in every novel-the importance of honesty:

If I have any complaints about my youth . . . one is that many well-meaning adults lied to me. Not spiteful lies with malicious intent but lies designed to prevent emotional and psychological pain, lies told by the people who cared about me most: my parents, teachers, relatives. They were lies designed to prevent disappointment, lies about the virtues of love, hard work, and any number of terms around which clichés blossom like desert flowers after a flash flood . . . . And I believed them, and became disillusioned when life turned out to operate by a different set of rules. (233-4)

Ideally, Crutcher believes, adults should tell young people the straight (and sometimes painful) truth about life-and about themselves. His many years as a child and family therapist have taught him that people are healed only by telling and hearing the truth, no matter how difficult, accepting responsibility, and reaching out to others for help and support. Terry Davis, novelist, critic, and Crutcher's long-time friend, says:

In the world Chris Crutcher creates in his stories the fact of human ghastliness doesn't negate the fact of human glory. 
Both qualities are indeed "facts" of life. Humanity is flawed, to be sure, but there is no fatal flaw in the human character, like the idea of original sin, that creates the necessity for divine intervention. There is no divine intervention. The people in Crutcher's world rise and fall, are saved or lost, by the degree to which they are connected to the humanity in themselves and others. (39-40)

Adults on and off the field, Davis and Crutcher agree, have the responsibility to connect to the children in their care and teach them to reach out to others.

As well as making these connections and being honest about the good and bad in life, the wisest adults also learn when to let go. Crutcher tells interviewer Betty Carter, “It’s risky business letting people have their own lives, particularly if they are our children. It's risky business giving up ownership, which, by the way, we never had in the first place" ("Eyes"). Even our biological children, Crutcher says, don't belong to us; they aren't our property. This doesn't mean ignoring what kids need and love, though. He comments to Joel Shoemaker: "There are lots of ways to help someone stretch other than by setting expectations too high to achieve. [Adults] will get a lot more 'stretching' mileage out of a kid by discovering that kid's passion and joining with him or her in it. [T]he primary strategy is to join and escalate" (97).

The adults in Crutcher's novels with the best opportunity to "join and escalate" are often coaches, but these men and women are not the perfectly wise and inhumanely patient creatures of earlier sports fiction for teens. In More than a Game, young adult novelist and critic Chris Crowe says that although Crutcher admires fictional athletic heroes like Clair Bee's Chip Hilton, he decided to make his athletes (and their coaches) more flawed than the superhumanly talented - and unbelievably nice-Hilton in order to have them "discover truth in more subtle ways” (40-1). Crutcher's novels are filled with portrayals of very human adults-kind but misguided, tortured and torturing, challenging and supportivealong with realistically-drawn young people who resent, resist, and sometimes even follow their advice (or at least learn from their mistakes).

This complex relationship between mentor and student seems to undercut Roberta Trites' position that the underlying purpose of the adolescent novel is to prepare young adults to acquiesce to the demands of the adult world. "Much of the genre," Trites says, is "dedicated to depicting how potentially out-of-control adolescents can learn to exist within institutional structures" (7). This doesn't square with what appears to be happening in Crutcher's novels. Young adults in his works are not successfully indoctrinated (no matter how hard adults try); they remain, for the most part, outside of the ideological systems that surround them. They learn that many adults, even those specifically appointed to take care of children, are not to be trusted, and they are drawn to those who challenge the status quo. Crutcher's heroes, more often than not, are confirmed in their stubborn resistance to the often-bullying authority of adults.

For example, in Crutcher's first novel, Running Loose (1983), main character Louie Banks confronts his aggressive and racist football coach, the appropriately-named Mr. Lednecky. In order to win a particularly important game, Lednecky tells his players to disable the star (and only black) player on the opposing team. Louie refuses to comply and is kicked out of the game, off the team, and eventually out of all highschool athletics for cursing the coach after his teammates seriously injure the player. Clearly, Lednecky represents the kind of coach Crutcher's kids must use as a cautionary tale.

Opposed to Lednecky is assistant football Coach Madison, who, as a new teacher, is initially unwilling to put his career in jeopardy by standing up to for Louie. However, Madison soon encourages Louie to participate on the track team, a diversion he desperately needs after the death of his girlfriend, Becky. When Lednecky insists that Louie should continue to be banned from playing sports, in order to teach him humility and build his character, Madison exemplifies Crutcher's ideal of good coaching. "I'm not building young men; I'm building athletes," Madison says. "What they do with that is their own business. . . . We can show them the ways to live their lives, but we can't tell them" (176). Coach Madison, Louie says, is "bound and determined to coach me in track and leave the rest of my life to me" (205).

With help from Madison, Louie is able to join the track team, in spite of the resistance from Coach Lednecky and the even "scarier" (88) former coach and principal, Mr. Jasper. As Madison says about Jasper, “A man's position only allows him so much room. After he uses it all and grabs for more, it has to 
be brought to someone's attention" (180). Louie takes this attitude to heart, and near the end of the novel, he smashes the principal's self-aggrandizing monument. The reader is left with a picture of a Louie Banks who has refused to accept "institutional structures," as Trites calls them. Instead, he has learned from Madison that he can "always take one more step" (187) and should "[r]un loose like always" (210). Louie has discovered how to push himself to achieve what he wants, to stand up for what he believes, and to distance himself from people who are trying to hold him back.

Chris Crowe says about the novel:

[R]eading about Louie's experiences in Running Loose will help teenagers realize that not all adults deserve their trust. As readers follow Louie through his story, they will learn with him how to distinguish truth from hypocrisy, reasoned actions from irrational actions, and good adults from bad adults. And, by "listening” to Louie's friends and mentors, especially Coach Madison . . . teenage readers will realize that despite the fact that young people lack adult status and authority, teenagers do have the power-and the responsibility-to resist adult hypocrisy and unethical behavior. (Crowe, “Running With” 362-3)

Louie not only can resist his principal and coach-he must. He learns through experience that "there's no use being honorable with dishonorable men" (215).

Throughout the novel, Coach Madison, his father, and other benevolent adults all support Louie. As Davis says: "It's probably more a comment on young adult literature than on Running Loose itself that so many reviewers mentioned the 'supportive' characterization of Louie's parents and other adults. Such supportive adult characters are relatively few in YA literature" (Davis, Presenting 59). What Crutcher manages to do so well-from his first novel on-is to carefully differentiate between good and bad adults and show when resistance is pointless and when it is truly warranted.

Stotan! (1986), Crutcher's second novel, features Max, a tough but insightful "Korean cowboy" (3) coach who pushes his swimmers to their limit physically and teaches them to triumph psychologically, as well. The novel centers on a week of intensive training during Christmas break for members of the swim team. The team members are Nortie, Jeff, Lion, and the narrator, Walker "Walk" Dupree. Each of them is troubled in one way or another, which is a typical state for Crutcher's main characters. Nortie is physically abused by his father and quits his job at a daycare center when he hits a child, fearing he is repeating the cycle. Jeff gets leukemia and is dying at the end of the novel. Lion's parents were killed in a boating accident, and he now lives alone above a tavern. Walk's older brother uses drugs and hangs out at a biker bar, much to Walk's distress.

Reflecting on life, Walk says, "I think if I ever make it to adulthood, and if I decide to turn back and help someone grow up, either as a parent or a teacher or a coach, I'm going to spend most of my time dispelling myths, clearing up unreal expectations. For instance, we're brought up to think that the good guys are rewarded and the bad guys are punished; but upon close scrutiny, that assumption vanishes into thin air" (181). This position is consistent with Crutcher's own view of life: Responsible adults should not lie to children about harsh realities. This novel shows that the challenge of the sport and the boys' team spirit can pull them through their troubles, but it neither turns away from those difficult issues nor provides a happy ending. Their coach is a stern taskmaster, but he knows that pushing them to the limit will teach them how much strength (and stubbornness) they really have, and he is fully aware of how much they will need those attributes.

In The Crazy Horse Electric Game (1987) main character Willie Weaver is a star pitcher, who, after being injured in a water skiing accident, suffers permanent motor-skill damage. As if that is not bad enough, Willie's family has also lost a child to SIDS, and consequently his parents have limited emotional resources with which to cope with his devastating injury and slow rehabilitation. His father, a former college football star, is especially angry at his son's apparent lack of progress, and at himself for contributing to the accident.

Fed up with his parents (and himself), Willie leaves home without telling anyone where he is going and ends up in Oakland, CA, where he encounters a benevolent (if sometimes violent) pimp and attends the One More Last Chance (OMLC) high school. Modeled after the alternative school where Crutcher taught, OMLC provides a space where administrators and teachers (especially Lisa, the P.E. coach) can help Willie regain his physical and psychological strength. Teaching him to find his "center" (168) and to take 
responsibility for his injury and recovery, Lisa, like all Crutcher's good coaches, doesn't lecture him about life. Instead, she uses sports to show Willie how to manipulate (and accept) his altered body and find his path to adulthood.

After more than a year, Willie returns home to Montana to find his family home sold, his parents divorced, his father a drunk, and his mother remarried. He stops there long enough to visit his mother's new family and then heads back to California. The ending is elegiac, with everyone longing for a past untouched by accident and death. In this novel adults are caring, if sometimes seriously flawed, but as in all of Crutcher's work, characters are saved by their connection to others and their dedication to athletics. At his graduation from OMLC, Willie sums up what he learned there:

Nobody here preached at me. Nobody told me everything would be okay, or that I should go back home to my parents and work things out when I knew the time for that wasn't here yet. They let me figure it out for myself; demanded that I figure it out for myself; but they never deserted me. (266)

This seems to be the essence of Chris Crutcher's good coaching: Let kids figure out what they need for themselves, and provide them with all the backup they need to make those discoveries.

In what is probably his most controversial work, Chinese Handcuffs (1989), protagonists Jennifer Lawless and Dillon Hemingway warily circle each other for the entire novel. Jennifer is a star basketball player and is being sexually abused by her stepfather. Dillon is a triathete and is coping unsuccessfully with his brother's suicide, his devastated family, and the uncomfortable romantic feelings he has for his brother's girlfriend, Stacey. The novel has both dramatically bad and heroically good coaches, monstrous as well as well-meaning (but troubled) parents.

Principal John Caldwell (another former coach) has, according to Dillon, "been so busy finding different ways to tell me what is and isn't good for me he never hears me" (7). Quickly, Dillon realizes that although Caldwell says that he wants Dillon to respect him, in reality he wants the young man to fear him. Calling fear respect, Dillon says, is "like fool's gold" (84). Once again, Crutcher faults adults for not telling the truth, for not calling things by their right names. When talking about Caldwell, Dillon expresses one of
Crutcher's core beliefs about sports: "[Caldwell] and his followers-and they are legion-have somehow confused athletic commitment with patriotism and human spiritual values, among other things" (85). As in Running Loose, Crutcher shows in this novel that athletics should never be turned into a metaphor for something else; it has its own inherent value.

Girls' basketball coach Kathy Sherman, unlike Caldwell, "knows what athletics is about better than anyone in the business. Her teams win and lose with grace and dignity, and her players never walk away empty-handed, never walk away without a lesson" (18). This, of course, infuriates people like Caldwell, who

hat[e] that she was by far the most successful coach in town-probably in the state-and that she accomplished that without the win-at-all-costs philosophy he considered so important in sports, and in life for that matter. She was always giving her kids a voice as she called it, and that just didn’t make sense. (101)

The lessons Sherman teaches are about hard work, grace, and personal dignity on the court, not about God, country, or defeating one's enemies in the larger world. While she is teaching those lessons, she is creating a safe place to be heard. In fact, Sherman's dedication to "giving her kids a voice" is what prompts Dillon to tell her about Jennifer's abuse and what leads her to shelter Jennifer while Dillon takes on her smart and dangerous stepfather. Sherman exemplifies what Crutcher thinks is best in an adult role model: She doesn't turn away from hard truths, and she is willing to put herself on the line for her kids.

Staying Fat for Sarah Byrnes (1993), Crutcher's fifth young adult novel, features Eric "Moby" Calhoun, a larger-than-average swimmer and friend of Sarah Byrnes, who at three years old was severely and deliberately burned by her father. At the beginning of the novel, Sarah has simulated catatonia to escape her increasingly deranged father: She is not speaking or responding and is in the psychiatric ward of a local hospital. Moby tries to bring her back to life.

He is helped by Ms. Lemry, his English teacher and swimming coach-a "thinking man's coach" (4). Like Kathy Sherman, Coach Lemry is intelligent, tough, and caring. When Moby and his family decide to take on Sarah's father, Lemry at first hides Sarah and eventually adopts her. At the end of the novel, 
Moby says, "Part of me wishes life were more predictable and part of me is excited that it's not. I think it's impossible to tell the good things from the bad things while they're happening" (215). Again readers see Crutcher's message: Life is unpredictable, unfair, and sometimes downright bad, but coaches like Lemry can help kids stand up to evil and even be excited by the challenge. ${ }^{1}$

Ironman (1995) alternates between main character Bo Brewster's first-person narrative and his letters to talk-show host Larry King. English teacher and coach Keith Redmond has it in for Bo after he quit the football team because he didn't like Redmond's humiliation-as-motivator coaching style. Bo's anger, which he directs at Redmond and the principal, keeps getting him suspended, and he winds up in anger management class with Mr. Nakatani, an Asian cowboy like Max, who "talks like Slim Pickens and dresses like his fashion guru is the Marlboro Man" (26). Mr. Nak, as he is called, takes on the role of mentor in this novel, while Bo becomes his own coach and trains for a triathlon.

Bo is also engaged in a power struggle with his dad, who always has to be right and is certain he knows what is best for his son. While Bo trains, his father buys a state-of-the-art bicycle for a competitor to teach Bo an ill-advised lesson in humility. (For Crutcher, all lessons in humility that adults give to children are ill advised.) However, Bo's fellow anger management students materially and emotionally support him during the race, and he performs well.

Mr. Nak says at the end of the novel:

“Ya know, I’ve heard folks say 'Life's not fair' in this group a lot. I've even said it myself when the occasion seemed to call for it. But that ain't correct. Life is exactly fair. People ain't fair, but life sure as hell is. Most of us just ain't willing to accept it. Life has Ironmen an' Stotans an' American Gladiators, an' Charles Mansons an' Jeffrey Dahmers. Life has every kind of holy man an' devil. If you're ever gonna beat all the anger an' hurt inside you, you're gonna have to learn to offset the awful with the magnificent. But that requires allowin' for both to have their place en the world. An' whether you allow it or not, it's there. The truth don't need you to believe it for it to be true." (180)

Like all positive adult figures in Crutcher's novels, Mr. Nak isn't afraid of telling the truth and empowering Bo and the others in his class with that truth. ${ }^{2} \mathrm{By}$ the end of the novel, the members of the anger management class, Bo included, have truly become a team, in large part because of Mr. Nak's brusque support and honest advice.

The protagonist of Crutcher's most recent (and arguably his best) work, Whale Talk (2001), does more than just coach himself; he assumes the responsibility of training others. In this novel, The Tao ("T.J.") Jones puts together a team of extremely unlikely swimmers to humiliate a football-player bully and an equally obnoxious coach. T.J. wants all of them to earn letter jackets and gain some confidence and pride, but he also wants to pop a few inflated egos. He chooses the kids to be on his team because of their mental disability, excessive weight, abusive parents, hyper intelligence, and/or physical handicaps. In spite of vigorous opposition by the football coach, who (correctly) recognizes that T.J. is in some way mocking the athletic department with his unconventional team, everyone but T.J. eventually earns a jacket.

Mr. Simet, an English teacher and swimming coach, aids T.J. in his quest. (The English teacher/ coach is a familiar Crutcher character.) Simet, T.J. says:

is a guy who always teaches you something, and it's not always about English or journalism. He was a hell of a swimmer himself in his younger years, when dinosaurs roamed the planet, and he seldom lets his classes forget what a spiritual experience it is to test yourself against that particular element. (12)

Simet, like Crutcher's other good coaches but clearly in the minority, is willing to step back and let the boys teach themselves and learn from each other. Many coaches, T.J. has learned the hard way, "always have to have it their way. They seem to listen, but in the end they make the rules and to hell with the people who have to follow them" (183). Like Kathy Sherman, Simet knows the value of giving kids a voice.

With the help of Simet and the other unlikely "Mermen" on his team, T.J., who has deliberately sabotaged his letter jacket prospects in a gesture of solidarity with his team members, comes to realize that:

[I]n the end I live[d] up to my name. The Tao-the real Tao, that knows and is everything-celebrates irony. Nothing exists without its opposite. I didn't earn a letter jacket because I could, and all my friends did because they couldn't. Some things really don't get any better. (204)

This is the lesson of all Crutcher's novels: There 
are no successes without failures, no good without the bad, no caring coaches and parents without equally damaging ones. Still, kids do manage, with the help of others, to outrun, out swim, and outplay most of the bad-most of the time.

Throughout Crutcher's work, his adolescent main characters learn to overcome obstacles, both physical and psychological, come to terms with hard realities, and confront bullying and dangerous adults in their lives. They do this often under pressure from difficult home lives, personal challenges, and adults who should be guiding them, not deliberately setting up roadblocks. Most importantly, though, as Davis says, Crutcher "makes help available to his characters-all the time" (Presenting 40). His young people don't have to do it alone: They have coaches like Simet and Nak, Lemry and Sherman, Lisa, Max, and Madison to inspire, challenge, and push them toward the finish line. Teachers and coaches outside of novels would do well to follow their example: tell the truth, give kids a voice, and, most importantly, let sports be simply about sports.

\section{Notes}

1 Roberta Trites says that in Staying Fat, Lemry "communicates indirectly but explicitly a key ideology in this novel of ideas: adults are responsible for protecting children" (81), but the novel actually shows that, for the most part, kids have to take care of themselves, ideally with some help from the adults. Perhaps the better way to put it is, as Davis comments, that the end of the novel is "a powerful example of a soul saved-or a longer stay in this world, at least-by human intervention and human love" (Davis, Presenting 43). There is no divine intervention in this novel, just caring adults and children's iron will.

2 Trites, however, says speeches like this assert the authority of adults over children. "When Mr. Nak communicates in loco parentis with an air of authority about how Bo can manage his anger," she says, "Nak is an adult narrator temporarily displacing the adolescent implied reader" (74). Yes, but Mr. Nak uses speeches like this to lead Bo and his classmates toward independence. In fact, Bo takes over the role of parent, suggesting that he and his father attend counseling sessions as a graduation present, and their relationship seems to be improving at the end of the novel.
Caren J. Town is Professor of English at Georgia Southern University. She teaches classes on adolescent and American literature, as well as methods courses for English Education students. Town has recently published The New Southern Girl (McFarland, 2004), which features the young adult novels of Mildred Taylor, Katherine Paterson, and Cynthia Voigt, and the works of other Southern women novelists on adolescence. She is also assistant editor of the Children's Literature Association Quarterly.

\section{Works Cited}

Carter, Betty. "Eyes Wide Open." Interview with Chris Crutcher. School Library Journal 46 (2000) 42-5. Ebsco. 28 Feb. 2005. <http://web5.epnet.com/ DeliveryPrintSave.asp? $\mathrm{b}=1$ \&.up=sid+F2d $>$.

Crowe, Chris. More Than a Game: Sports Literature for Young Adults. Lanham, MD: Scarecrow, 2004.

_-_. "Running with, Not from, Running Loose." Censored Books II: Critical Viewpoints, 1985-2000. Ed. Nicholas J. Karolides. Lanham, MD: Scarecrow, 2002. 357-65.

Crutcher, Chris. Athletic Shorts. New York: Greenwillow, 1991. (Laurel-Leaf, 1992).

-_- Chinese Handcuffs. New York: Greenwillow, 1989.

(Laurel-Leaf, 1991).

- - . The Crazy Horse Electric Game. New York: Greenwillow, 1987. (Harper Tempest, 2003).

-_-. Ironman. New York: Greenwillow, 1995.

-_- King of the Mild Frontier. New York, Harper Collins, 2003.

_-_. Running Loose. New York: Greenwillow, 1983. (LaurelLeaf, 1986).

-_- Staying Fat for Sarah Byrnes. New York: Greenwillow, 1993.

-_- Stotan! New York: Greenwillow, 1986.

-- Whale Talk. New York: Harper Collins, 2001. (Laurel-Leaf, 2002).

Davis, Terry. "A Healing Vision." The English Journal 85 (1996): 36-41.

-_- Presenting Chris Crutcher. New York: Twayne, 1997.

Shoemaker, Joel. "Crutch, Davis, and Will: That Was Them, This is Now." Interview with Chris Crutcher, Will Weaver, and Terry Davis. VOYA 94 (2002): 94-9.

Trites, Roberta Seelinger. Disturbing the Universe: Power and Repression in Adolescent Literature. lowa City: U of lowa P, 2000. 